\title{
Becoming Educultural: Collaborative Projects in the Arts
}

\author{
Dianne Macdonald \\ Deputy Principal, Manurewa Intermediate School, Auckland
}

\begin{abstract}
Manurewa Intermediate students were given an experience only the arts can provide as they collaboratively researched, responded to and celebrated a school mural project. The mural project was initiated by Shane Hansen through the Principal lain Taylor and coordinated by Dianne Macdonald, a Professional Learning Leader at Manurewa Intermediate School. The thrust of the project: To paint an artwork environment that told the school's story 'Listen to Culture'. The mural, titled Pumanawatanga, which is 2.4 metres high and 20 metres long, was designed and painted by thirty Year 7 and Year 8 students in Terms 3 and 4 in 2009, in collaboration with local New Zealand artist Shane Hansen. The underpinning aim of this project was to support students' learning in arts education through a focus on 'culture'. Shane's influences include his Maori, Chinese and European heritage, the environment, his family and other New Zealand artists such as Gordon Walters and Dick Frizzell. Shane draws from a world of bold colours and what has been described as an optimistic post-modern playfulness.
\end{abstract}

\section{Storied experience}

Keywords: Arts, collaboration, culture

Shane grew up and went to school in Manurewa. He wanted to work with and give back to this community that had contributed to his own development as a contemporary New Zealand artist. Across two terms Shane worked with the students of Manurewa Intermediate School to develop the ideas for the mural. Initially he brought in his own works and shared the stories behind them. This provided opportunities for deeper contemplation by the students. From Shane the students learned about artistic style, the use of a strong clean line and text, digital imaging, compositional methods and the printing and painting techniques involved when using large sheets of plywood.

The narrative for the mural came from Professor Angus Macfarlane's conceptualisations of culturally-responsive strategies that are explained and demonstrated by what he refers to as the Educultural Wheel (Macfarlane, 2004). Professor
Macfarlane is based at the University of

Canterbury, and is the University's first Professor of Maori Research. Affiliating to the Te Arawa waka and its confederate tribes, he has a keen interest in making classrooms and schools happier and more productive environments for Maori learners and their teachers. Four key cultural concepts drive the directions of the Educultural Wheel (see figure 1). Pumanawatanga is at the hub and represents the morale, tone and pulse of the school - around which the four key inter-related and overlapping concepts are woven.

On the mural itself the word 'Manaakitanga' is included subtly in the black, white, green and red curves in one section of Pumanawatanga. Manaakitanga exemplifies an ethic of caring that runs through Manurewa Intermediate School's Moving On Up (MOU) Magic and the three keys to success - we look after each other; we look after property and our environment; we look after ourselves.

Peeling back the layers prompts reflection on the intricate nature of the local history of Manurewa, the Rimu school house and Whaia te iti Kahurangi, representing the educational journey of the Year 7 and Year 8 children of Manurewa Intermediate School, and the vision we have that when they leave us they will soar like the kite of Tamapahore, from which Manurewa is named. Whaia te iti Kahurangi, has come to symbolise how Manurewa Intermediate School is 'Motoring and Moving On Up'.

The students in the mural project were selected by classroom teachers from across the school and did not necessarily know each other at the start of the project. The criteria was for the students to be interested in drawing and making art. As Natalie (a Year 7 student) explains:

"I liked how people said they were shy at first

but then when they knew everybody well they could all work together... I know now we all could communicate properly with each other."

These words sum up another spoke in the Educultural Wheel - the ethic of bonding signified in Kotahitanga. The collaboration forged between the artist, the teacher and the students was particularly evident in the voluntary school holiday 
painting workshops when the group took over the school hall for a few days. The visits from Kirsty, his wife, and the days Shane's young son Nikau would join the students signify the ways relationships are built. Whanaungatanga also symbolises Shane's connections with the students, not only as an artist but as a former pupil of the area with whanau living in Manurewa. He gave and continues to give Manurewa students rich experiences.

The 5:00am morning blessing for Pumanawatanga was magical. Led by local kaumatua Wally Thompson, the blessing was attended by the principal, students, Shane, whanau, board trustees, staff, local principals and community partners from Council and the University of Auckland. A surreal atmosphere was created by the moonlight, the people present and by Pumanawatanga cloaked in tarpaulins against the golden glow from the outdoor lights. Among the guests was Professor Angus Macfarlane whose work inspired the educational values that sit behind this work. The kaumatua invited Professor Macfarlane to join him in leading the recital of ancient karakia (incantations) and contemporary inoinga (prayers).

Pumanawatanga represented a beginning step in the journey of students and staff at Manurewa Intermediate School becoming educultural. The school explored the principles of the Educultural Wheel in 2009 through the mural-making process and, in 2010, the staff experienced professional development with Professor Macfarlane. He described and demonstrated the concepts and explained their alignment to the craft of classroom management and student motivation. The intention of the professional development day was for teachers to grasp a firm understanding of the concepts in order for them to become manifest in the school and wider community.

The thrust of his teaching and research activities is concerned with the exploration of culturally-responsive concepts and strategies that positively affect professional teaching practice and student outcomes. It is through these four key Maori principles of Angus Macfarlane's Educultural Wheel - 'Kotahitanga' (Ethic of Bonding), 'Whanaungatanga' (Building Relationships), 'Manaakitanga' (Ethic of Caring) and 'Rangatiratanga' (Teacher Effectiveness) that Manurewa Intermediate School hopes to inspire future students and teachers to participate in bringing alive our school vision: Adventurous Risk Takers: Persistent Focused Achievement!

\section{AUTHOR'S PROFILE}

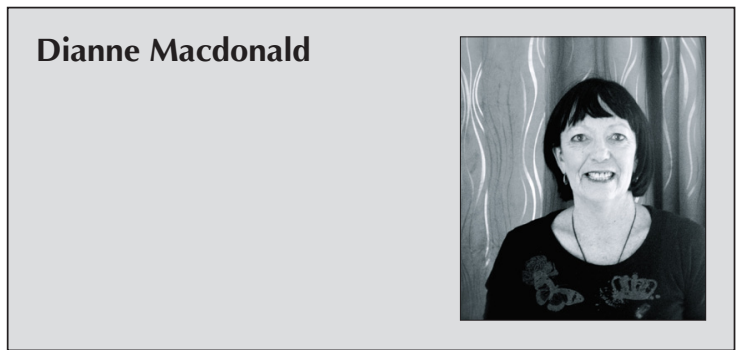

Dianne Macdonald is a Deputy Principal at Manurewa Intermediate School in South Auckland with responsibilities for leading the professional learning and mentoring of the teaching staff, and is also Head of the Nga Toi Faculty. She has a background in teaching the visual arts and worked as a lecturer in education at the University of Auckland. This is where she first met with the work of Professor Angus Macfarlane and the Educultural Wheel as a model for culturally responsive pedagogies. In 2011, Dianne has been awarded a Ministry of Education Teacher Study Award to complete her Master's Thesis on Educative Mentoring Practices.

EMAIL

dianne@manurewaint.school.nz

\section{ACKNOWLEDGEMENTS}

I am grateful for the vision and passion of my Principal, lain Taylor, who supported the project from its inception. Working with contemporary NZ artist Shane Hansen was an opportunity for my own personal professional development in the arts. To the thirty students from Manurewa Intermediate who rose to the challenge of creating an outstanding piece of community art - a very big thank you. Dr Jill Smith, from the University of Auckland, was generous with her time and feedback as the story developed and of course Professor Angus Macfarlane from the University of Canterbury, who has been inspirational in my own teaching and learning.

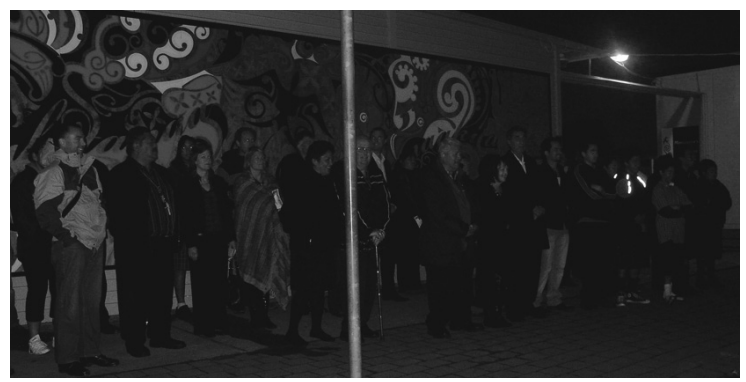

